\title{
A GLOBALIZAÇÃO E SEUS EFEITOS NAS RELAÇÕES DE PODER: QUESTÕES ACERCA DA MIGRAÇÃO E SUAS FORMAS DE EXPLORAÇÃO
}

\author{
LA MUNDIALIZACIÓN Y SUS EFECTOS EN LAS RELACIONES \\ DE PODER: CUESTIONES A CERCA DE LA MIGRACIÓN Y SUS \\ MANERAS DE LA EXPLOTACIÓN
}

\author{
Vanessa Alexsandra de Melo Pedroso' \\ Luísa Vanessa Carneiro da Costa²
}

\begin{abstract}
RESUMO: O presente trabalho pretende estudar questóes sobre o fluxo migratório em razăo dos efeitos da globalizaçăo, de modo a pensar que o poder econômico é um fator agravante frente ao tráfico de seres humanos e a exploraçăo da migraçăo. Dessa forma, os principais autores que deram aporte teórico para esta pesquisa foram: Therborn (2001), Vieira (1999), Garachana (2008) e Sassen (2008). Tratando-se de uma pesquisa bibliográfica, e exploratória, de abordagem qualitativa. Podemos perceber o fluxo migratório como resultado de uma série de fatores, a propósito: os acontecimentos políticos, econômicos e sociais colaboram para a instabilidade da migraçáo, como reflexo, a marginalizaçăo decorrente das implicaçôes da globalizaçăo instauradas no campo da violência, neste caso, a violência de gênero, ao pensar a mulher migrante, na
\end{abstract}

1 Pós-doutora pelo Programa de Pesquisa em Ciências sociais, Crianças e Adolescentes na América Latina da rede: PUC-Sáo Paulo (BR) e Centro Latino Americano de Ciências Sociais (CLACSO). Doutora em Direito Penal pela Universidad Complutense de Madrid (España) onde investigou o crime de Tráfico de Seres Humanos e a interferência do marco do Código Penal Espanhol de 1995 para a prevençáo de referido delito no âmbito da Uniăo Européia. Diplomada em Estudos Avançados (DEÂ) pela mesma Universidade e especialista em Relaçôes Internacionais na era da Globalizaçáo pelaUniversidade Católica de Pernambuco (Brasil). Atualmente é Professora de Direito Penal da Universidade Católica de Pernambuco, onde, também, leciona, na condiçáo de Professora Permanente, em seu Programa de Pós-Graduaçáo em Direito (Mestrado e Doutorado). E, ainda, líder do grupo de pesquisa "Direitos Fundamentais: Instrumentos de concretizaçáo" (Plataforma Lattes). Tem experiência na área de Direito, com ênfase em Direito Público, atuando principalmente nos seguintes temas: movimento migratório - com atençâo ao fenômeno da feminizaçăo da imigraçăo, tráfico internacional de seres humanos e imigraçăo ilegal, exploraçăo sexual e prostituiçăo - futuro do Direito Penal e Direito penal da globalizaçâo. vanessampedroso@gmail.com

2 Mestranda em Direito - Universidade Católica de Pernambuco - UNICAP (2017). Pós-graduanda em Direitos Humanos: Educaçăo e Ressocializaçăo - Universidade Candido Mendes - UCAM (2017). Bacharela em Direito pelo Centro Universitário do Vale do Ipojuca - DeVryUNIFAVIP. Controladora Interna no Instituto de Previdência e Servidores de Capoeiras-PE (IPSEC). Foi Pesquisadora no Grupo de Estudos e Pesquisas Interdisciplinares Sobre Direitos Humanos Mércia Albuquerque (GEPIDH - Mércia Albuquerque). Realizou Extensăo Universitária: DHiálogos: Ciclo de Debates Sobre Sociedade e Direitos Humanos. Possui interesse nas áreas de Direitos Humanos, Criminologia, Gênero, Medidas de Segurança, Cárcere e Tráfico de Drogas. luisavanessa1@hotmail.com 
esfera trabalhista, quanto à precarizaçăo do trabalho, o impacto sobre os trabalhadores migrantes e o papel da imigraçăo, dentre outras formas de exploraçáo deste campo que atinge várias pessoas e Estados do mundo.

PALAVRAS-CHAVE: Globalizaçăo. Migraçăo. Economia. Tráfico de seres humanos.

RESUMEN: El trabajo estudia cuestiones del flujo de la migración bajo los efectos de la mundialización desde el poder de la economía como hecho que aumenta el fenómeno del tráfico de seres humanos e la explotación de la migración. Los autores que conducen teóricamente la investigación son Therborn (2001), Vieira (1999), Garachana (2008) e Sassen (2008). La investigación bibliográfica y exploratoria de carácter cualitativa. Se puede percibir que el flujo de la migración es resultado de un conjunto de factores, es decir, los hechos políticos, económicos y sociales que, a su vez, colaboran para la instabilidad de la migración y traen como reflejo una violencia decurrente de los procesos de la mundialización. En ese caso nos interesa la violencia en lo que atañe la precariedad del trabajo de los trabajadores migrantes y en especial a la mujer migrante y su derecho al trabajo digno, lejos de cualquier posibilidad de victimizarlas.

PALABRAS CLAVE: Mudialización. Migración. Economía. Trata.

\section{INTRODUÇÃO}

A definiçăo do título do trabalho baseia-se em um sistema jurídico sistemático, que segue as condiçóes dogmáticas e as condiçōes aplicáveis aos estrangeiros legais e/ou clandestinos que migram para posterior exploraçăo, seja formal ou informal.

Esta circunstância baseia-se no fato de que, quando se trata da questăo da imigraçăo, năo é possível, portanto, distanciar, completamente, as questóes relacionadas à identificaçăo dos movimentos, de circunstâncias econômicas, políticas e sociais a que um determinado Estado enfrenta e, talvez, um continente.

Desta forma, neste trabalho, analisar-se-á as adversidades que influenciaram o movimento migratório e a exploraçăo da migraçăo, dando causa as questóes econômicas decorrentes das relaçóes de poder.

Procura-se entender, através destas perspectivas, o quanto o processo de globalizaçăo reflete nas relaçóes de constantes crises políticas, dessa forma, teve-se como problema de pesquisa: Quais as intercessôes entre globalizaçăo e migraçăo frente às relaçôes de poder econômico?

Como objetivo geral, tem-se a necessidade de: Estudar questôes sobre globalizaçâo e migraçăo, frente às relaçóes de poder e para os objetivos específicos foram estabelecidos: Discutir sobre globalizaçăo e seus efeitos no poder econômico, a partir das formas de migraçăo; Analisar, sob o aspecto das coordenadas econômicas, as formas de migraçăo, frente ao atual processo de globalizaçăo.

A escolha do tema se deu pelo interesse de aprofundar uma temática que se entende 
como de grande relevância, de modo que é fruto de estudos que vêm sendo realizados ao longo da disciplina: Globalizaçăo, migraçăo e tráfico de seres humanos, surgindo, a partir disso, a inquietaçáo e curiosidade em compreender de que forma ou, quiçá formas - bem como os efeitos - o poder econômico que promovem o fluxo migratório.

Para o contexto acadêmico, o presente trabalho parte de um estudo com pouca visibilidade em pleno século XXI, haja vista a frequente marginalizaçăo da migraçăo econômica e a grande desigualdade social, decorrente da era globalizada. De forma que, para o âmbito social, este trabalho traz uma história da realidade em que vivem as milhóes de pessoas vítimas de uma estrutura social que traça padrōes de opressăo daquele que nâo se encaixa nos conservadores ditames traçados pela sociedade dos "bons".

A ideia surge, entăo, da necessidade de apontar os elementos que compōem o fluxo migratório năo apenas nas regiōes de saída, mas também naquelas consideradas de chegada, uma vez que esses pontos consistem, por sua vez, no objetivo final do comércio de pessoas.

Esta maneira de abordar o assunto é muito importante, uma vez que a discussăo do objeto proposto tem uma transcendência prática que levanta um debate social crítico que se baseia na busca por práticas de equidade. Tal debate é realizado através da resoluçáo de muitas dúvidas e questóes que surgem em todo o desenvolvimento de idéias que fundamentam esse trabalho, embora sejam justificadas em outras ciências diferentes das do campo jurídico.

A partir disso, é possível afirmar que o trabalho traz uma discussăo de grande relevância e que, infelizmente, tem pouca visibilidade na sociedade tradicional e conservadora que vivemos.

\section{PENSANDO QUESTÕES SOBRE GLOBALIZAÇÃO E SEUS EFEITOS NO PODER ECONÔMICO}

O presente trabalho tem a finalidade de analisar questôes sobre globalizaçăo e migraçăo econômica, de modo a estudar relaçóes entre o poder econômico, capital e polarizaçăo dos regimes políticos frente às formas de exploraçáo da migraçăo, no contexto do tráfico de seres humanos.

Neste cenário, serâo discutidas questôes que nos remetam a pensar o que é globalizaçăo, quais os efeitos da globalizaçăo, e ainda, assuntos direcionados à questóes econômicas, a partir das formas de migraçấo, fazendo uma abordagem à introduçấo do tráfico de pessoas.

Há de se falar, inicialmente, em globalizaçâo levando em consideraçăo alguns conceitos básicos, bem como seus efeitos conduzidos pela economia, processos históricos e dimensōes políticas.

Desde a década de 80 que vem sendo utilizado o termo globalizaçăo para designar as açôes de características transnacionais em relaçăo ao funcionamento do mundo. No entanto, estabelecer um conceito fixo do que se torna a globalizaçăo através de suas implicaçōes e políticas é uma tarefa muito difícil, pois, em princípio, o fenômeno acima mencionado é apresentado como uma circunstância generalizadora da economia de 
mercado para todos os Estados do mundo.

Desse modo, pensando um conceito básico a definir o que seria globalizaçăo, segundo Therborn (2001), que entende partir, basicamente de três correntes, onde a mais evidente e mais simples delas consiste na ideia de globalizaçáo enquanto qualquer coisa que queiramos que ela seja, o que é uma resposta coerentemente nominalista, pois defende que a globalizaçăo deveria indicar a existência de algo novo nesse mundo.

Dessa ideia, Therborn (2001, p. 124) discorre sobre um segundo conceito que caracteriza a ideia de globalizaçăo:

Uma segunda resposta adequada implicaria em situar o conceito em discursos reais atuais e, a partir daí, talvez continuar a especificar as definiçōes individuais. Desde o final da década de 80 , a noçăo de globalizaçăo surgiu em, pelo menos, cinco tipos centrais de discurso. 0 principal deles é o econômico, que se refere a novos padróes de comércio, investimento, produçáo e empreendimento. Um segundo tipo, geralmente derivado do primeiro, é o sócio-político, concentrando-se no papel cada vez menor do Estado e de um tipo de organizaçáo social a ele associada. Em terceiro lugar, a globalizaçáo surgiu como centro de um discurso e de um protesto sócio-críticos, como uma nova forma que assumem as forças adversas: o inimigo da justiça social e de valores culturais particulares. Há outros dois discursos, mais especializados, mas igualmente importantes. Existe o discurso cultural, dos estudos antropológicos e culturais, que apresenta a globalizaçăo como fluxos, encontros e hibridismo culturais. Por fim, como responsabilidade social, a globalizaçăo é parte de um discurso ecológico e de preocupaçôes ambientais planetárias.

“Um terceiro conceito para globalizaçáo seria o de caráter reflexivo, o qual pondera: a globalizaçáo está sendo concebida de diversas formas, mas para propósitos de análise social científica, entendo que esta é a mais proveitosa" conforme dispóe Therborn (2001, p. 124).

Meza (1996) estabeleceu um conceito fixo do que vem a ser globalizaçáo, mediante suas implicaçōes teóricas e políticas, dizendo ser uma tarefa árdua, já que em princípio o referido fenômeno se apresenta como circunstância generalizadora da economia de mercado a todos os Estados do mundo, ou seja, a globalizaçăo é um paradigma de fundamentaçấo econômica e, também, um modelo ideológico que, em tese, possibilita um maior desenvolvimento de todos os Estados do globo, bem como um assentamento definitivo das instituiçôes democráticas.

No entanto, a globalizaçāo concentra seus benefícios econômicos em três polos específicos, a saber, a Europa, EUA e Japâo possibilitando, ainda, o empobrecimento das regióes que estăo ao redor desses três grandes países (HERNÁNDEZ, 1997). Na realidade, é possível afirmar que a globalizaçăo é um fenômeno que opta por concentrar mercados econômicos que, por sua vez, se tornam centros de decisóes transnacionais, já que possuem o poder econômico mundial.

Neste sentido, faz-se necessário refletir se a globalizaçăo năo consiste, tăo somente, na concentraçấo de poder e submissăo econômica daqueles que nâo alcançam um sistema de produçăo de riquezas.

Se náo, note-se a pouca oportunidade de crescimento e desenvolvimento econômico e social que os países năo detentores de riquezas tem sofrido. Sem contar uma verdadeira precarizaçấo do trabalho e um numero excessivo de desempregados, gerando, assim, desigualdades sociais e dependência econômica do exterior. 
Faz-se, entăo, necessário um processo de realinhamento constitucional decorrente dessa globalizaçâo centralizada e neste sentido, pensa-se na ideia dos três movimentos que Vieira (1999), vem chamar de regionalizaçăo, cosmopolitanismo ético e globalizaçăo econômica.

Desse modo, Vieira (1999), dispóe que a regionalizaçâo resta representada pela Uniâo de Estados, com fins específicos; o cosmopolitanismo ético aparece em decorrência do movimento de um sistema universal de direitos humanos, onde o último movimento, chamado de globalizaçáo econômica, busca estabelecer um hábitat ideal para a livre circulaçấo e atuaçấo do capital transnacional por todo o globo.

$\mathrm{O}$ que se percebe, diante desses três movimentos que foram mencionados é que os direitos humanos constituem o melhor exemplo do processo de constitucionalizaçấo, considerando a importância da Declaraçáo Universal dos Direitos Humanos, seu objetivo e a respectiva funçăo.

A esse respeito, Vieira (1999, p. 30):

Assim é que surgiu a Declaraçăo Universal dos Direitos Humanos, com o objetivo de estabelecer um novo horizonte ético, a partir do qual a relaçăo dos Estados com seus cidadăos pudesse ser julgada por um paradigma externo ao próprio direito de Estado. A Declaraçăo, é bom que se diga, năo surgiu com a pretensăo de transformar-se em Direito Internacional, como uma hard law. Embora seja o principal instrumento e certamente o mais conhecido dos documentos de direitos humanos [...].

De toda forma, há quem fale que a Declaraçăo Universal é apenas um dos passos adotados pelo processo de constitucionalismo globalizado, de modo que considera-se que o sistema global também foi fundado na Carta da ONU, no ano de 1945, bem como na Declaraçăo Universal de 1948, năo bastante, também estaria fundamentado em outros Tratados de proteçâo dos refugiados.

Considerando o que é globalizaçâo, sua relaçăo com o poder econômico, seus efeitos e processo de surgimento Vieira (1999), fala, ainda, como o sistema global de proteçăo aos direitos humanos conseguiu adquirir mais consistência, de forma que essa incorporaçăo se deu a partir da adoçăo da Convençâo Internacional de Direitos Civis e Políticos, ambas em 1966.

Nessa perspectiva, Campilongo (1996), entende que:

Para muitos teóricos do Direito, a globalizaçâo envolve a passagem de um contexto de vinculaçăo entre o Estado e o direito para uma situaçăo de pluralismo das fontes normativas (um direito social primário que surge dos "fatos do direito" um direito dos juristas e, por fim, um direito estatal). [...]

Assim, é interessante pensar o quanto a sociedade global é complexa e está interligada à determinaçóes externas, pois que, ao mesmo tempo que possibilita diferentes alternativas e possibilidades, impóe as consequências dos riscos em um padrâo que envolve em sua dimensăo, novas formas de comércio, investimento, produçăo e empreendimento. Sem contar que, ainda, é um derivado sócio-político que surgiu como centro de um discurso e de um protesto sócio-crítico, como uma nova forma que assumem as forças diversas. 
A partir de um balanço mais objetivo, é interessante frisar sobre efeitos e resultados dessa era globalizada em razáo de uma sociedade traçada por padróes eurocêntricos e marcadores de exclusăo político-econômica.

Rattner (1995) aduz que o processo de globalizaçâo, embora conduzido pela economia, deve ser apreendido, também, em suas dimensōes políticas, histórico-culturais e espaciais-ecológicas. Contrariamente à visâo idealizada de uma progressăo linear de mercados regionais integrados para uma sociedade una e global, a realidade apresenta, para esse autor, uma fragmentaçăo do espaço político com novas barreiras e mercados protegidos.

Através disso, percebe-se a necessidade de um balanço mais objetivo que olhe para os cidadăos periféricos e pense na populaçấo mais vulnerável, socialmente e financeiramente falando, no intuito de minimizar os problemas da fome, do desemprego, das favelas, da violência, por exemplo. De um modo geral, observa-se que quanto mais há uma desigualdade do nível salarial, acarretando na seletividade e hierarquia de poderes, predomina os conflitos e torna conturbada a relaçáo de igualdade socioeconômica.

Nota-se, em termos práticos, que, todos os dias os conflitos entre grupos de interesse que lutam por fatias decrescentes do produto social săo agravados pelos multiplicados choques entre grupos étnicos e religiosos longamente reprimidos, frustrados e desesperançados face à inoperância do sistema e das instituiçôes. Efetivamente, à medida que a competiçáo pelos mercados se acirra, os ricos e poderosos tornam-se mais soberanos e os pobres, em número crescente, mais miseráveis (RATTER, 1995).

Por sua vez, notamos como a globalizaçâo, mais precisamente as razóes de cunho econômico săo fortes e influentes nos setores de serviços prestados e na seletividade de emprego, de forma a serem grandes influentes para o capital financeiro e industrial.

Para Ratter (1995), um fator agravante desse processo de polarizaçăo e exclusâo é constituído pela perda paulatina da capacidade do Estado de levantar recursos, via tributos e impostos, para atender às demandas cada vez mais urgentes, năo somente das massas, mas também das classes médias angustiadas pelo desemprego. É dizer, demandas fundamentadas no custo e baixa qualidade da educaçăo, bem como na falta de segurança e deterioraçăo generalizada da qualidade de vida.

A observaçăo desta circunstância leva a dois problemas essenciais. O primeiro traz uma reflexăo sobre o fato de que o fenômeno da globalizaçăo, ao reconhecer as liberdades do caráter econômico, estabelece no mundo real a existência da escravidăo como regra de sociedades atuais.

Já uma segunda problemática/reflexăo, leva à pensar sobre a concentraçăo de benefícios econômicos em pólos específicos. Por sua vez, promove diretamente, um novo sistema de observaçăo do espaço e do tempo, de acordo com Castells (1996, p. 62), uma vez que existe uma fusăo dos conceitos acima mencionados, proporcionando assim uma conexáo imediata entre diferentes pontos ao redor do planeta.

Dessa forma, esta fusáo de espaço e tempo promove de maneira indireta, processos agregados à globalizaçăo, pois que tal fenômeno, em verdade, trás consigo uma interdisciplinariedade de pressupostos que levam muitos setores sociais a uma verdadeira desordem. Se năo é assim, note-se o que aduz Boaventura de Souza Santos quando lembra que "Aquilo que habitualmente chamamos de globalizaçâo sâo, de fato, 
globalizaçōes, pois se trata de conjuntos diferenciados de relaçōes sociais" (SANTOS, 2002, p. 29).

Feitas essas consideraçôes a respeito do processo de globalizaçấo, suas causas e efeitos, frente às consideraçôes de direitos humanos, passa-se a análise de sua influência a partir das formas de exploraçâo da migraçăo.

\section{CONTEXTO MIGRATÓRIO E SUAS FORMAS DE EXPLORAÇÃO}

Neste tópico serăo tratadas questóes acerca da migraçăo e possíveis formas de exploraçăo, pensando, portanto, em suas coordenadas econômicas que marcam o atual processo de globalizaçấo.

Inicialmente, de acordo com Martini (2005), é preciso entender como a globalizaçăo afeta os deslocamentos espaciais da populaçấo. Nos dias de hoje, o horizonte do migrante năo se restringe à cidade mais próxima, nem à capital do estado ou do país. Seu horizonte é o mundo - vislumbrado no cinema, na televisâo, na comunicaçâo entre parentes e amigos. O migrante vive em um mundo onde a globalizaçáo dispensa fronteiras, muda parâmetros diariamente, ostenta luxos, esbanja informaçóes, estimula consumos, gera sonhos e, finalmente, cria expectativas de uma vida melhor.

Ao mesmo tempo, faz-se necessário lembrar que a globalizaçăo, por meio de um sistema político neoliberal, consegue afastar, cada vez mais, a tentativa de igualdade de classes, partindo, assim, do pressuposto que o capitalismo se alimenta das desigualdades para ter a possibilidade de se manter.

Neste talante, a pedra de toque passa a ser a compreensăo năo só econômica do fenômeno da globalizaçăo, mas também política e social, haja vista que a livre mobilidade dos bens, implícita no discurso da globalizaçâo, nâo está diretamente relacionada à livre mobilidade dos diferentes cidadáos do mundo, fornecendo como antes dito, uma nova construçăo do conceito de fronteiras.

Dessa forma,

A história da humanidade registra, desde o seu aparecimento na face da Terra até hoje, repetidos movimentos de migraçăo e de fixaçăo de populaçóes em várias regióes do globo. Os seres humanos sempre se movimentaram, por instinto, com o desejo de conhecer e explorar o desconhecido ou impulsionados por problemas políticos, econômicos, sociais, religiosos, guerras, ou através da combinaçâo de dois ou mais desses fatores. No decorrer dos séculos aconteceram muitos movimentos migratórios de proporçóes diferentes, sendo alguns de grandes dimensōes, os quais influíram significativamente na evoluçăo histórica do gênero humano. (DEZAN, 2007, p. 18)

Sendo assim, percebemos que com o fluxo migratório, o processo de acúmulo de capital tende a crescer e tomar sentido no que se refere à saída de zonas opacas em direçâo às zonas luminosas, por exemplo, sempre buscando melhores condiçôes de vida através de novas oportunidades de trabalho.

De acordo com Walzer (1998, p. 45), é verdade que a mudança de etnicidade é um processo natural de fluxos migratórios de qualquer ordem, pois é o resultado da 
reuniăo de padróes de comportamento, idéias estruturadas por crenças, costumes e valores transmitidos coletivamente de uma determinada sociedade. Assim, por exemplo, diz-se que, quando os imigrantes de certa regiâo chegam à Espanha -, por exemplo - eles trazem consigo um forte fardo de emoçōes típicas de seus países, dificultando o conhecimento e a manifestaçăo dos valores da sociedade a que eles chegam.

Com isso, é possível pensar na ideia de capitalismo e desequilíbrio social, pois

O grande desequilíbrio social está inerente ao capitalismo, de forma que a acumulaçáo de bens em poucas máos e a farta distribuiçáo da miséria para muitos, habita o inimigo, ou seja, a contradiçăo fundante deste modo de produçáo está inerente à injustiça e a iniquidade (SAFFIOTI, 2004, p. 14).

Desse modo, é possível traçar um perfil de migrantes econômicos, já que estes, geralmente, estăo considerados dentro de uma classe vulnerável.

É importante dizer que, na maioria das vezes, o desenvolvimento de atividades em condiçóes de precariedade nos Estados desenvolvidos sugere uma possível melhoria das condiçôes de vida em relaçăo às condiçôes em que esses imigrantes moram em seus países de origem. Fato que leva à reflexăo de que os elementos de atraçăo năo têm significado quando săo observados isoladamente, porque esses elementos, necessariamente, devem receber apoio do que podem ser chamados de elementos de expulsāo nos países de partida (BECUCCI, MASSARI, 2003, p. 13).

Percebe-se, assim, que o deslocamento de espaços variados, tem como principal característica do público migrante as estratégias de sobrevivência e de mobilidade social da populaçáo. A partir disso, é importante notar que no estudo da migraçăo é necessário, sempre, ter em mente as condiçóes que vinculam os países de destino com os Estados de orientaçăo, ou melhor dizendo, de saída ou de origem desses cidadâos.

Entende Martini (2005) que a migraçăo é inevitável e tem o potencial de ser bastante positiva para o desenvolvimento e a reduçăo da pobreza. As políticas que partem desse princípio terăo mais êxito do que aquelas que tentam se opor, de forma intransigente, à globalizaçăo e/ou à migraçăo de pessoas no espaço.

É interessante observar que há um crescente fluxo migratório, mais precisamente no contexto global, que segundo Marinucci (2015), é caracterizado por uma difundida crise econômico-financeira, a chegada de imigrantes e solicitantes de refúgio desperta, nâo raramente, sentimentos e atitudes de solidariedade e acolhida, mas também reaçôes alarmistas, xenófobas e racistas. A globalizaçâo da violência bélica, que atinge também os países ocidentais, alimenta ainda mais um generalizado clima de suspeita em relaçăo a qualquer imigrante, inclusive entre aqueles que fogem de guerras, de redes de tráfico de pessoas e de violaçôes generalizadas de direitos humanos.

Diante disso, percebemos o quanto as práticas xenófobas sâo marcadores de preconceito e violência quando se refere ao contexto migratório, de forma a criminalizar a migraçâo e com isso, a construçâo de muros e barreiras que dificultam a liberdade dessa classe.

Percebemos o quanto há exclusâo dos imigrantes, por parte dos Estados, o que ocorre frequentemente na Alemanha, por exemplo, onde foi adotada uma política de fechamento das fronteiras, que era chamada de "zero imigraçăo", depois recebendo o slogan "aqui nâo tem lugar". Essas campanhas externavam marcadores manifestando racismo e xenofobia, essas práticas também eram comumente visualizadas nos países 
da América Latina, onde observou-se grandes crises socioeconômicas dirigidas pelas classes políticas.

Por sua vez, conforme trata Marinucci (2015), essas reflexóes atestam a profunda complexidade da relaçăo entre criminalidade, migraçăo e direito. Embora sofram numerosas violaçóes de direitos humanos, tanto nos países de origem como naqueles de trânsito e de chegada, muitos migrantes e solicitantes de refúgio, com frequência, acabam sendo perseguidos por dispositivos legislativos que visam, antes que o respeito da dignidade do ser humano, o controle do excedente social.

Fator que ganha traços de segregaçāo e violência com índices mais elevados, sâo os marcadores de gênero, tendo em vista a marginalizaçâo da mulher migrante, o que resta ainda mais evidente quando o mercado de trabalho imigrante é destinado a mulheres também imigrantes, por exemplo.

Isso pode ser observado ao longo da história das sociedades tradicionais, onde as mulheres náo foram encorajadas a sair de sua casa, nem a ir além dos limites da unidade familiar, pois sua responsabilidade consistia em cuidar de seus filhos e, em algumas sociedades, no cuidado dos pais idosos. A busca de uma vida melhor além do horizonte que determina a casa sempre foi um privilégio dos homens.

Com isso, podemos pensar o quanto nossa estrutura social apresenta traços extremamente machistas e misóginos, vez que pode ser repensado o lugar que o feminino ocupa frente a um meio social fincado em privilégios e conservadorismo.

O espaço que as mulheres ocupam em grau de privilegio ainda é, de certo modo, insignificante, de forma que a opressăo e a violência contra a vida social da mulher ainda é traçada por desigualdades.

Diante de uma sociedade intensamente hierárquica, traçada por padróes subalternos decorrentes das questóes de gênero, as mulheres mulas sâo, rotineiramente vítimas de violências.

De acordo com Garachana (2008), o homem é fonte de renda para sua família, migra para outra cidade ou país, para ganhar algum dinheiro porque, onde vivem, prevalecem as condiçóes inerentes à pobreza ou à pobreza extrema e é impossível obtê-lo devido à falta de oportunidades de trabalho. No início, a mulher/família recebe dinheiro das remessas do homem que a deixou e, em troca, esse homem, pede-lhe para ficar no mesmo lugar à sua espera.

Partindo da analise da migraçăo a partir do feminino é possível perceber o quanto a mulher é considerada como um mero elemento de continuidade familiar. Se năo note-se que a figura de macho detém todo o poder de decisāo sob o migraçâo do ente feminino nos fluxos migratórios familiar.

Outra maneira de perceber a exclusăo e repressăo às minorias passa-se, pois nas oportunidades de inserçấo ao mercado de trabalho, frente ao processo migratório e suas características.

Desta maneira, é possível notar o quanto os processos de exclusáo e de seletividade partem de uma estrutura social traçada pelas marcas do tradicionalismo e do privilégio.

Ou seja, essa exclusăo supóe uma estrutura estatal para atender aos fins do capital através da marginalizaçáo do imigrante. Mas, note a seleçâo das obras destinadas 
aos nativos e aos imigrantes e, além disso, o abismo existente, principalmente, na relaçăo salarial e nas garantias trabalhistas entre esses dois atores sociais (PEDROSO, 2010, p.68).

Dessa maneira, notamos que a história da imigraçăo econômica foi, em larga medida, projetada pela história dos trabalhadores e até mesmo pelas transformaçóes desses mesmos trabalhadores estrangeiros em comunidades étnicas que nâo compartilham necessariamente a mesma nacionalidade.

No entanto, Sassen (2008) afirma que hoje, o fenômeno migratório ultrapassa os limites dessas duas histórias, uma vez que os cidadâos como um todo observam a imigraçăo como uma transgressâo, contribuindo para a manifestaçăo de uma nova história desse processo.

Essa questăo foi bem detalhada em 2004 por José Ignacio Antón Prieto (p. 252/253) onde o autor discorre sobre as atitudes que os cidadăos castelhano-leoneses admitem que a entrada de migrantes está diretamente relacionada a delinquência e insegurança dos nativos, pois que mais de $40 \%$ dos entrevistados admitem existir uma relaçâo entre imigrantes e os delitos de propriedade e homicídios. O autor aponta, ainda, que para um número considerável de entrevistados este vínculo é muito maior nos casos de prostituiçâo.

Dois anos depois, Montserrat Pérez Viso (p. 136) chega a afirmar que a opiniăo pública passou a considerar que se existem mais imigrantes, existem mais delitos, pois $51 \%$ da populaçâo considera que o aumento da imigraçăo está diretamente relacionada aos incrementos da delinquência.

Para Sassen (2008), este novo momento do processo migratório apresenta múltiplas características ${ }^{3}$ que resultam da reuniăo das circunstâncias presentes nos nossos dias. Certas circunstâncias sâo representadas pela desestabilizaçăo de hierarquias formais de poder centradas no Estado e que, por sua vez, é formada pelo surgimento de novas instituiçóes globais que vâo desde mercados eletrônicos financeiros até regimes de direitos humanos.

Nesta perspectiva podemos perceber resquícios ocidentalizados quando falamos em direitos humanos. Dessa forma observamos o quanto as estratégias de direitos ainda sâo arcaicas em razâo da liberdade de cultura e valores.

Assim, uma perspectiva ocidentalizada ainda se faz presente neste campo, o que é fácil notar os marcadores sociais de opressâo, fincados no conservadorismo de uma sociedade globalizada, que prega padróes e estereótipos culturais, invisibilizando outros costumes e valores.

De acordo com o pensamento de Sassen (2008), essas instituiçōes globais, por sua vez, permitiram uma multiplicaçăo de dinâmicas e atores políticos informais em um espaço que o autor chama de "cidades globais"4 exigindo, portanto, a existência de um novo Tribunal Penal Internacional.

3 Conforme informaçóes coletadas do Movimento Migratório Internacional.

4 Cidades globais sáo uma espécie de nova zona fronteiriça, tanto para a capital global, como para os novos atores políticos informais, segundo SASSEN, Saskia. 
Neste contexto, a observaçăo dessas "cidades globais" leva a evidências claras de uma reestruturaçâo da demanda trabalhista nesses núcleos, separada em três grupos diferentes, sendo o primeiro um grupo com alto grau de especializaçăo e, portanto, recebendo a renda mais alta ou, mesmo a renda média, um segundo grupo formado por empregos mal remunerados, que têm pouca qualificaçấo, mas possuem o pleno domínio do idioma e, pelo mesmo motivo, o grupo de imigrantes que produzem serviços de qualquer ordem (SASSEN, 2000, p. 503/524).

O que se pode perceber é que no mundo global, a realizaçăo de uma nova economia, de serviços onde as oportunidades de emprego sâo de baixa qualidade, prevalecem sob às expectativas de uma melhoria para a classe trabalhista. É nesse clima geral que muitos migrantes se inserem no mercado de trabalho dos países de trânsito e de destino.

Esta convivência da associaçăo de atores segregados com a intençăo de promover o benefício de uma existência comum para eles é mais evidente quando o mercado de trabalho imigrante é destinado a mulheres também imigrantes.

Desse modo, buscamos identificar a globalizaçăo como sendo instrumento estrutural da migraçáo para grandes centros econômicos. Analisando, portanto, como a globalizaçâo gera uma escravidăo de diferentes formas, variando conforme o contexto migratório e suas formas de exploraçăo.

\section{CONSIDERAÇÕES FINAIS}

A ideia deste trabalho é identificar a globalizaçăo econômica como instrumento estrutural da migraçăo para os grandes centros econômicos mundiais.

Para tanto, este trabalho tentou contextualizar o fenômeno da imigraçăo durante um marco temporal, e tangencialmente, foi contemplando a globalizaçăo como um instrumento que promove a imigração atual.

Nâo se trata aqui de afirmar que o fenômeno migratório ou talvez o objeto geral de estudo deste trabalho, isto é, o comércio de pessoas e o cruzamento ilegal de fronteiras é um fato dos tempos modernos ou mesmo o resultado da globalizaçâo, porque isso seria uma falsa percepçăo da história do mundo, já que, migraçăo regular ou nâo, bem como o comércio de pessoas existe desde os tempos mais remotos.

Porém, por outro lado, năo se pode negar que a globalizaçăo como conhecemos na atualidade, termina por destacar as diferenças entre os Estados de uma maneira que revela falsas oportunidades de riqueza em Estados considerados centrais.

Fato que, por sua vez, acaba expandindo, nos cidadăos dos países periféricos, o desejo de emigrar para os países centrais em busca de uma melhor qualidade de vida econômica promovendo, como conseqüência, uma estratificaçấo do mercado de trabalho para estrangeiros que chegam de países considerados de Terceiro Mundo.

Este fenômeno migratório, baseado na atual concentraçăo econômica, apresenta diferentes efeitos e transformaçōes que, ao longo da elaboraçâo deste trabalho, foram enumerados e a partir do qual podemos apontar a forte mudança na identidade dos cidadăos dos Estados centrais e também, nos cidadăos provenientes de Estados periféricos, uma vez que estes passam a assumir valores de cultura transnacional, admitindo em muitas ocasiōes a denominaçâo de "cidadăos do mundo". 
Ao mesmo tempo, o fenômeno da feminizaçăo da migraçăo também foi identificado, ou seja, ao contrário do que aconteceu no passado, a mulher reage hoje como a célula que inicia a cadeia de migraçăo tanto nas emigraçóes nacionais, quanto no contexto migraçăo internacional.

Referida circunstância possivelmente tenha sido evidenciada devido à incorporaçấo de mulheres no mercado de trabalho salarial nos Estados desenvolvidos. Fato que associado aos elementos de expulsăo dos estados periféricos, promove a existência do que é considerado um proletariado feminizado nos países centrais. 


\section{REFERÊNCIAS}

BECUCCI, Stefano; MASSARI, Monica. Globalizzacione e criminalitá. Ed. Laterza. Roma, 2003.

CAMPILONGO, Celso Fernandes. Teoria do direito e globalizaçăo econômica. In: VIEIRA, Oscar Vilhena; SUNDFELD, Carlos Ari. Direito Global. Săo Paulo: Editora Max Limonad, 1999. cap. 3.

CASTELLS, Manuel. La era de la información, economia, sociedade y cultura. La sociedade red. vol. 1. Alianza editorial. Madrid, 1996.

DEZAN, M. D. de S. Impactos da Imigraçâo Japonesa Sobre a Diversidade Cultural na Organizaçâo do Espaço Geográfico Piracicabano-SP. Rio ClaroSP: Dissertaçăo (mestrado) - Universidade Estadual Paulista, Instituto de Geociências e Ciências Exatas, 2007.

GARACHANA, María Josefa Lopéz. Retos que enfrentam las mujeres solas em el sigloXXI, em La Igualdade no es uma Utopía. Nuevas Fronteras: Avances y Desafios. Anales del $10^{\circ}$ Congresso Internacional e Interdisciplinar Mundos de Mujeres. Thomson. Madrid, 2008.

HERNANDÉZ, Juan Ramón Capella. Fruta prohibida: Una aproximación histórico - teorética al esadio del derecho y del estado. Trotta: Madrid, 1997.

MARINUCCI, Roberto. Criminalizaçâo das migraçôes e dos migrantes. Disponível em: http://www.scielo.br/scielo.php?script=sci_arttext\&pid=S1980-85852015000200007. Acesso em: 23 out. 2017.

MARTINI, George. A globalizaçâo inacabada migraçōes internacionais e pobreza no século 21. Disponível em: http://www.scielo.br/scielo.php?script=sci_arttext\&pid=S0102-88392005000300001. Acesso em: 19 out. 2017.

MEZA, Raúl Bernal. La globalizacón: ¿ um processo y una ideologia? In. Realidad Económica. IADE. n 39. Buenos Aires, abril/maio de 1996.

PRIETO, José Ignacio Antón. “Inmigración y Delito: En el imaginario colectivo. Alternativas a una relación perversa", In. ÁLVAREZ, Fernando Pérez. Serta in memoriam Alexandri Baratta. Ediciones Universidad Salamanca. Salamanca, 2004.

PEDROSO. Vanessa Alexandra de Melo. La Nueva Esclavitud: El comercio de seres humanos versus el cruce ilegal de fronteras em la legislación española. 2010, 448 f. (Tese) Doutorado em Direito Penal, Departamento de Derecho Penal, Universidad Complutense de Madrid, Faculdad de Derecho, Madrid, 2010. 
RATTER, Henrique. Globalizaçăo: em direçăo a um mundo só?. Disponível em: https://www.google.com.br/url?sa=t\&rct=j\&q=\&esrc=s\&source=web\&cd=3\&ca$\mathrm{d}=\mathrm{rja}$ \&uact=8\&ved=0ahUKEwibl8ep2_jWAhVL6oMKHXeqDo8QFgg8MAI\&url=http\%3A\%2F\%2Fwww.scielo.br\%2Fscielo.php\%3Fscript\%3Dsci_arttext\%26pid\%3DS0103-40141995000300005 \&usg=AOvVaw1FBENd1HNd̈Gfpz9JYcpr5L. Acesso em: 18 out. 2017.

SAFFIOTI, Heleieth Iara Bongiovani. Gênero, patriarcado, violência. Sáo Paulo: Editora Fundaçăo Perseu. Abramo, 2004.

SANTOS, Boaventura de Souza. As tensōes da modernidade. Página electrónica: http:// www.dhnet.org.br/direitos/militantes/boaventura/ boaventura4.html. Acesso em: 11 fev. 2018.

SASSEN, Saskia. Inmigrantes em la Ciudad Global. Disponível em: http://www.nodo50. org/tortuga/article.php3?id_article=4093. Acesso em: 19 jul. 2008.

SASSEN, Saskia. Women's burden: Counter-geographies of globalization and the feminization of survival. Journal of internacional affairs. Spring. 2000.

THERBORN, Goran. Globalizaçăo e desigualdade: questôes de conceituaçăo e esclarecimento. Sociologias, Porto Alegre, v. 3, nº 6, p. 122-169, jul/dez 2001.

VIEIRA, Oscar Vilhena. Realinhamento Constitucional. In: VIEIRA, Oscar Vilhena; SUNDFELD, Carlos Ari. Direito Global. Săo Paulo: Editora Max Limonad, 1999. cap. 1.

VISO, Montserrat Pérez. Marco normativo de la inmigración en el Estado español, In. CANLE, Inés C. Iglesias (Dir.). Inmigración y Derecho. Tirant lo Blanch n. 432. Valencia, 2006.

WALZER, Michael. Tratado sobre la tolerância. Paidós Iberica. Barcelona, 1998. 